\title{
IDENTIFIKASI BAKTERI DAN UJI KEPEKAAN TERHADAP ANTIBIOTIK PADA PENDERITA TONSILITIS DI POLIKLINIK THT-KL BLU RSU. PROF. DR. R. D. KANDOU MANADO PERIODE NOVEMBER 2012-JANUARI 2013
}

\author{
${ }^{1}$ Rinny Olivia Sembiring \\ 2John Porotu'o \\ ${ }^{2}$ Olivia Waworuntu
}

\author{
${ }^{1}$ Kandidat Skripsi Fakultas Kedokteran Universitas Sam Ratulangi Manado \\ ${ }^{2}$ Bagian Mikrobiologi Fakultas Kedokteran Universitas Sam Ratulangi Manado \\ Email: rinnysembiring@ymail.com
}

\begin{abstract}
Tonsillitis is inflammation of palatine tonsil as part of the Waldeyer'sring. Tonsillitis most commonly caused by viral orbacterial infection. The purpose is to determine such an insidence of the type of bacterials from patient's (with tonsillitis) throat swabs examination at the Department of Otolaryngology RSUP Prof. Dr. R.D Kandou Manado and also to determine such an insidence of the bacterial's sensitivity ofantibiotics that commonly used on tonsillitis case. This research was taken at the Department of Otolaryngology RSUP Prof. Dr.R.D Kandou Manado by using prospective descriptive study method as well as examining 20 samples from the patients with tonsilitis. The result, $75 \%$ samples showed bacterial's growth. There were found 6 types of bacterials. The following bacterials are $10 \%$ eschericia coli, $10 \%$ of staphylococcus aureus, $40 \%$ of streptococcus sp., $5 \%$ of branhamella catarrhalis, $5 \%$ of enterobacter aerogenes and 5\% of alcaligenes faecalis. On sensitivity of antibiotics, $66,67 \%$ Levofloxacin, 66,67\% of Cefriaxon, 53,3\% of Amoxicilin clavulanic, 13,3\% Ciprofloxacin. The differences in place, time, and history of antibiotics therapy, could caused the differences in type of bacterials among the tonsillitis patients.
\end{abstract}

Keywords: tonsillitis, type of bacterial, sensitivity test.

\begin{abstract}
Abstrak: Tonsilitis merupakan peradangan tonsil palatina yang merupakan bagian dari cincin waldeyer.Tonsilitis adalah infeksi (virus atau bakteri) dan inflamasi pada tonsil.Tujuan penelitian ini mendapatkan gambaran jenis kuman pada pemeriksaan hapusan tenggorokan penderita tonsilitis di Poliklinik THT-KL BLU RSUP Prof. Dr. R. D. Kandou Manado dan juga gambaran tentang kepekaan kuman terhadap beberapa antibiotika yang biasa digunakan pada tonsilitis. Penelitian ini bersifat prospektif deskriptif lewat pengambilan sampel dari pasien Poliklinik THT-KL.Dari 20 sampel yang diuji, didapatkan 15 sampel (75\%) menunjukkan pertumbuhan bakteri dan 5 sampel (25\%) tidak ada pertumbuhan bakteri. Bakteri yang ditemukan ada6 jenis bakteri yang terdiri dari 2 sampel escherichia coli (10\%), 2 sampel staphylococcus aureus (10\%), 8 sampel streptococcus sp (40\%), 1 sampel branhamella catarrhalis (5\%), 1 sampel enterobacter aerogenes (5\%), 1 sampel alcaligenes faecalis(5\%). Sedangkan sensitifitas antibiotika yang paling tinggi adalah Levofloxacin 10 sampel (66,67\%) dan cefriaxone 10 sampel (66,67\%), kemudian amoxicilin calvulanic 8 sampel (53,33\%), ciprofoxacin 2 sampel (13,33\%). Perbedaan tempat, waktu, serta riwayat pernah mendapatkan terapi antibiotika, dapat menyebabkan perbedaan pola kuman
\end{abstract}

Kata kunci: tonsilitis, pola bakteri, uji kepekaan. 
Tonsilitis merupakan peradangan tonsil palatina yang merupakan bagian dari cincin waldeyer. ${ }^{1}$ Tonsilitis adalah infeksi (virus atau bakteri) dan inflamasi pada tonsil. ${ }^{2}$ Fungsi cincin waldeyer adalah sebagai benteng bagi saluran makanan maupun saluran napas terhadap serangan kuman-kuman yang ikut masuk bersama makanan/ minuman dan udara pernapasan. Selain itu, anggota-anggota cincin waldeyer ini dapat menghasilkan antibodi dan limfosit. $^{3}$ Tonsilitis kronis pada anak dapat disebabkan karena anak sering menderita ISPA atau tonsilitis akut yang tidak diterapi adekuat. ${ }^{4}$

Berdasarkan survey epidemiologi penyakit THT di 7 provinsi (indonesia) tahun 1994-1996, prevalensi tonsilitis kronis sebesar 3,8\% tertinggi kedua setelah nasofaring akut $(4,6 \%){ }^{5,6}$ berdasarkan data medical record tahun 2010 di RSUP dr. M. Djamil padang bagian THT-KL sub bagian laring faring ditemukkan tonsilitis sebanyak 465 dari 1110 kunjungan di poliklinik sub bagian laring faring dan menjalani tonsilektomi sebanyak 163 kasus, sedangkan jumlah kunjungan baru penderita tonsilitis kronik di RS Wahidin Sudirohusodo Makassar periode Juni 2008-Mei 2009 sebanyak 63 orang. ${ }^{7}$ Dibandingkan dengan jumlah kunjungan baru pada periode yang sama, maka angka ini merupakan 4,7\% dari seluruh jumlah kunjungan baru. Insiden tonsilitis kronis di RS. Dr. Kariadi Semarang 23,26\%. Sedangkan penelitian yang dilakukan di Malaysia pada Poli THT Rumah Sakit Sarawak selama 1 tahun dijumpai 8.118 pasien, dalam jumlah pen-derita penyakit tonsilitis kronis menempati urutan keempat yakni sebanyak 657 (81\%) penderita. ${ }^{5,8}$

Tonsilitis bisa disebabkan oleh beberapa jenis bakteri dan virus, Antara tonslitis akut dan tonsilitis kronik memiliki perbedaan penyebabnya yaitu Tonsilitis akut lebih sering disebabkan oleh kuman grup A streptococus $\beta$-hemolyticus, pneumococcus, streptococcuc viridans dan streptococcuc pyrogenes, sedangkan tonsilitis kronik kuman penyebabnya sama dengan tonsilitis akut tetapi kadang-kadang kuman berubah menjadi kuman golongan gram negatif. $^{1,9}$ Infiltrasi bakteri pada lapisan epitel jaringan tonsil akan menimbulkan reaksi radang berupa keluarnya leukosit polimorfonuklear sehingga terbentuk detrius. Detrius ini merupakan kumpulan leukosit, bakteri yang mati dan epitel yang terlepas. Secara klinis detrius ini mengisi kriptus tonsil dan tampak sebagai bercak kekuningan. ${ }^{8}$ Faktor predisposisi timbulnya tonsilitis kronik ialah rangsangan menahun dari rokok, beberapa jenis makanan, higene mulut yang buruk, pengaruh cuaca, kelelahan fisik dan pengobatan tonsilitis akut yang tidak adekuat. ${ }^{1,9}$ karena proses radang berulang yang timbul maka selain epitel mukosa juga jaringan limfoid terkikis, sehingga pada proses penyembuhan jaringan limfoid digantikan oleh jaringan parut yang akan mengalami pengerutan sehingga kriptus melebar. Secara klinis kriptus diisi oleh detrius. Proses berjalan terus sehingga menembus kapsul tonsil dan akhirnya menimbulkan perlekatan dengan jaringan disekitar fosa tonsilaris. Pada anak proses ini disertai dengan pembesaran kelenjar limfa submanibula. ${ }^{1}$

Penggunaan antibiotik yang luas pada pengobatan infeksi saluran pernapasan atas, tanpa bukti empiris yang jelas, telah meningkatkan terjadinya resisten berbagai strain mikroba dari staphylococcus aureus, streptococcus pneumonia, haemofilus influenzae, moraxella catarrhalis dan lainnya terhadap antibiotik. ${ }^{4}$

Gangguan tonsilitis kronis dapat menyebar dan menimbulkan komplikasi melalui perkontinuitatum, hematogen atau limfogen. Penyebaran perkontinuitatum dapat menimbulkan rinitis kronis, sinusitis, dan otitis media. Penyebaran hematogen atau limfogen dapat menyebabkan endokarditis, artritis, miositis, nefritis, uveitis, iridosiklitis, dermatitis, urtikaria, furunkulosis, dan pruritus. ${ }^{9}$

Berdasarkan masalah tersebut diatas maka dapat disimpulkan bahwa tonsilitis masih merupakan masalah kesehatan yang perlu mendapatkan perhatian khusus, karena angka kejadiannya yang cukup tinggi di indonesia. Begitu pula masalah komplikasinya yang dapat menyebabkan masalah kesehatan yang cukup serius. Berdasarkan 
hal-hal tersebut, dalam rangka menyelesaikan Karya Tulis Ilmiah Sarjana Keokteran, maka penulis mengadakan penelitian khusus mengenai Pola Kuman dan Kepekaannya terhadap antibiotika pada penderita tonsilitis di poliklinik THT-KL BLU RSUP Prof. Dr. R. D. Kandou selama periode November 2012-Januari 2013. Kemudian diuji kepekaannya terhadap antibiotika di Laboraturium Mikrobiologi RSUP Prof. Dr. R. D. Kandou Manado.

\section{METODE PENELITIAN}

Penelitian yang dilakukan menggunakan metode deskriptif dengan pendekatan studi prospektif. Waktu penalaksanaan penelitian pada bulan November 2012Januari 2013 dan penelitian ini dilaksanakan di Poliklinik THT-KL RSUP Prof. dr. D.R Kandou Manado dan Laboraturium Mikrobiologi RSUP Prof. dr. R.D Kandou Manado. Sampel penelitian adalah semua pasien penderita tonsilitis yang akan dilakukan pemeriksaan hapusan tenggorok di THT-KL BLU RSUP Prof. dr. D.R Kandou Manado. Kriteria inklusi yaitu pasien tonsilitis yang bersedia dilakukan pemeriksaan hapusan tenggorok sedangkan kriteria eksklusi yaitu pasien tonsilitis yang tidak bersedia dilakukan hapusan pemeriksaan tenggorok. Alat pada penelitian ini yaitu lidi kapas steril, spatula lidah, kaca objek, lampu spritus, sengkelit, cawan petri dan mikroskop. Bahan pada penelitian ini yaitu media transport : Stuart, media isolasi : agar darah, agar nutrien dan Mac Conkey, media identifikasi : TSIA, Simon sitrat, air pepton dan semisolit, carbol cristal violet, larutan lugol, alkohol 96\%, air Funhsin, dan cakram-cakram (disk) obat antibiotika untuk uji kepekaan. Pada penelitian ini dilakukan uji kepekaan untuk mengetahui apakah kuman sensitif, intermediate atau resisten terhadap obat antibiotika yang dingunakan.

\section{HASIL PENELITIAN}

Dari hasil penelitian yang dilakukan terhadap 20 sampel usapan tenggorok dari penderita tonsilitis di poliklinik THT BLU RSUP Prof. dr. R. D. Kandou ditemukan 15 sampel ada pertumbuhan bakteri dan 5 sampel tidak ada pertumbuhan bakteri.

Selama penelitian dari november 2012Januari 2013 telah dilakukan penelitian terhadap pasien penderita tonsilitits di poliklinik RSUP. Prof. dr. R. D. Kandou didapatkan 15 sampel dengan diagnosis tonsilitis akut maupun kronik yang belum di terapi antibiotika dan 5 sampel yang tidak ada pertumbuhan antibiotika.

Dari 20 sampel yang didapat, maka digolongkan dalam 4 kelompok umur yaitu 0-12 tahun 9 orang (45\%), 13-17 tahun 2 orang (10\%), $18-59$ tahun 8 orang (40\%), dan $>60$ tahun 1 orang (5\%) dan dari 20 sampel yang didapat, yang berjenis kelamin laki-laki sebanyak 55\%, sedangkan jenis kelamin perempuan $45 \%$.

Setelah dilakukan pemeriksaan laboraturium mikrobiologi di RSUP.Prof. Dr.R.D Kandou pada 20 sampel usapan tenggorok, didapatkan 15 sampel yang ada pertumbuhan kuman sedangkan yang 5 tidak ada pertumbuhan kuman dan dari hasil pemeriksaan lab ditemukan 6 jenis bakteri yang terdiri dari 2 sampel escherichia coli (10\%), 2 sampel staphylococcus aureus (10\%), 8 sampel streptococcus sp (40\%), 1 sampel branhamella catarrhalis (5\%), 1 sampel enterobacter aerogenes (5\%), 1 sampel alcaligenes faecalis(5\%) dan 5 sampel tidak ada pertumbuhan (25\%).

Sebelum menentukan kepekaan bakteri terhadap masing-masing antibiotika yang digunakan maka pada penelitian ini perlu diketahuiterlebih dahulu mengenai standart diameter zona hambatan menurut National Commite For Clinical Laboratory Standarts (NCCLS).

Sensitifitas yang paling tinggi adalah Levofloxacin 10 sampel (66,67\%) dan cefriaxone 10 sampel (66,7\%), kemudian amoxicilin calvulanic 8 sampel (53,33\%), ciprofoxacin 2 sampel (13,33\%). Sedangkan angka resisten yang paling tinggi adalah clindamycin dan erithormycin.

\section{BAHASAN}

Berdasarkan penelitian yg dilakukan di poliklinik THT-KL BLU RSUP Prof. dr. 
R.D. Kandou Manado dalam kurun waktu 3 bulan november 2012 - januari 2013 didapat 20 pasien dengan diagnosis tonsilitis kronik maupun akut. Dari hasil penelitian yang terdiri dari kelompok umur 0-12 tahun 9 pasien (45\%), 13-17 tahun 2 pasien (10\%), 18-59 tahun 8 pasien (40\%), dan $>60$ tahun 1 pasien (5\%). Hal ini berdasarkan jurnal penelitian dari Rajesh ${ }^{22}$ yang menyatakan 70\% kasus tonsilitis dialami oleh anak sekolah yang brumur 6 tahun keatas. Sedangkan hasil penelitian dari Sri S yang membagi usia berdasarkan dua golongan umur yaitu 3-7 tahun 15 sampel (75\%) dan 8-12 tahun 5 sampel (25\%).

Dari 20 penderita tonsilitis yang berobat di poliklinik THT-KL RSUP Prof.Dr.R.D.Kandou Manado dari bulan November 2012 - Januari 2013 ditemukan enderita laki-laki 11 orang (55\%) dan penderita perempuan 9 orang (45\%). Hal ini berbeda dengan penelitian Juenvie di mana penelitian pada bulan juni-juli 2010 didapatkan jumlah penderita perempuan 8 orang $(61,45 \%)$ dan laki-laki 5 orang $(38,46 \%) .^{10}$

Pada pemeriksaan yang dilakukan terhadap 20 sampel hapusan tonsil, diperoleh hasil pertumbuhan bakteri pada 16 sampel (80\%) dan 4 sampel (20\%) tidak ada pertumbuhan bakteri. Bakteri yang di temukan terdiri dari streptococcus sp 8 sampel (40\%), staphylococcus 2 sampel(10\%), escherichia coli 2 sampel (10\%), branhamella catarrhalis 1 sampel (5\%), enterobacter aerogenes 1 sampel (5\%), alcaligenes faecalis 1 sampel (5\%), dan tidak ada pertumbuhan 4 sampel (25\%). Hal ini sesuai dengan pustaka dari Rajesh ${ }^{22}$ yang ada bahwa 30\%-40\% kasus tonsilitis disebabkan oleh group A streptococcus $\beta$ hemolyticus, pneumococcus, streptococcuc viridans dan streptococcuc pyrogenes, sedangkan tonsilitis kronik kuman penyebabnya sama dengan tonsilitis akut tetapi kadang-kadang kuman berubah menjadi kuman golongan gram negatif. Pada penelitian memiliki perbedaan jumlah sampel dan jenis kuman yang diperoleh. Pada pemeriksaan 13 sampel ditemukan 10 sampel penderita tonsil yang diperoleh hasil pertumbuhan kuman dan 3 sampel yang tidak ada pertumbuhan kuman. Dari kuman yang di dapat dari hasil pemeriksaan Laboraturium Mikrobiologi RSUP. Prof. Dr. R. D. Kandou Manado di dapatkan jenis kuman stafilococcus albus 5 sampel (38,46\%), streptococcus non hemolyticus 3 sampel (23,07\%), klebsiella 1 sampel (7,69\%), bacillus subtilis (kontaminan) 1 sampel $(7,69 \%) .^{10}$

Pada uji kepekaan digunakan 6 jenis antibiotika yaitu amoxycilin calvulanic, ciprofloxacin, levofloxacin, erithromycin, clindamycin, cefriaxone. Hasil penelitian menunjukan semua bakteri yang didapat pada identifikasi kuman peka terhadap antibiotika levofloxacin. kemudian bakteri escherchia coli, staphylococcus aureus, streptococcus sp, enterobacter aerogenes, alcaligenes faecalis peka terhadap antibiotika cefriaxon kecuali bakteri branhamella catarrhalis yang tidak peka terhadap antibiotika cefriaxon. staphylococcus aureus, streptococcus sp, enterobacter aerogenes, alcaligenes faecalis peka terhadap antibiotika amoxicilin calvulanic. Sedangkan escherichia coli dan staphylococcus aureus peka terhadap ciprofloxacin.

Dari hasil penelitian yang didapat bahwa semua bakteri sudah resisten terhadap antibiotika clindamycin dan eritromisin.

\section{SIMPULAN}

Dari 20 sampel usap tenggorok, didapatan bahwa 15 sampel menunjukkan pertumbuhan bakteri dan 5 sampel tidak ada pertumbuhan bakteri. Bakteri yang terbanyak adalah Streptococcus sp dan jenis antibiotika yang paling peka yaitu Levofloxacin dan Cefriaxon, sedangkan antibiotika yang paling resisten yaitu Clindamycin.

\section{UCAPAN TERIMA KASIH}

Terima kasih ditujukan kepada:

1) dr. Olivia Pelealu, Sp. THT-KL sebagai Dosen Penguji I.

2) dr. Standy Soeliongan, M.Repro, Sp. MK (K) sebagai Dosen Penguji II. 
3) Semua pihak yang secara langsung maupun tidak langsung yang telah memberikan ide/gagasan dalam penulisan skripsi ini.

\section{DAFTAR PUSTAKA}

1. Soepardi, E A dan Nurbaiti Iskandar, Jonny Bashiruddin, Restuti, R. D, Buku Ajar Ilmu Kesehatan Telinga-Hidung-TenggorokanKepala Leher, $6^{\text {th }}$ Ed, Fakultas Kedokteran Universitas Indonesia, Jakarta, 2007: 221

2. Muscari, E.M, Keperawatan Pediatrik; Infeksi Saluran Pernapasan Bagian Atas. 3rd Ed, Penerbit Buku Kedokteran ECG, Jakarta, 2005 : 216-217

3. Herawati S, Rukmini S, Buku Ajar Ilmu Penyakit Telinga Hidung Tenggorokan;Anatomi Faring. Penerbit Buku Kedokteran ECG, Jakarta, 2004 : 1315

4. Pulungan RM, jurnal MIKROBIOLOGI TONSILITIS KRONIS, Jurnal Fakultas Kedokteran universitas andalas Padang.

5. Mindarti F, Rahardjo, S.P, Kondrat L, The Relationship Between Titer Of Anti Streptolisin $\mathrm{O}$ and Clinical Symptoms In Patient With Chronic Tonsilitis. Jurnal, 2010 Fakultas Kedokteran Universitas Hasanuddin Makasar.
6. Farokah. 2005. Laporan Penelitian: Hubungan Tonsilitis Kronik dengan Presentasi Belajar Siswa Kelas II sekolah dasar di Kota Semarang. Availabe from: http://eprints.undip.ac.id/12393/1/2005FK3 602.pdf (Diakses pada 7 April 2011)

7. Sakka Indo, Sedjawidada Raden, Kodrat Linda, Rahardjo Pratiwi Surti. Laporan Penelitia: Kadar Imunoglobullin A sekretori pada pemderita tonsilitis kronik sebelum dan sesudah tonseloktomi. Fakultas Kedokteran Universitas Hasanuddin Makasar

8. Kufung, M. Tonsilitis Akut dan kronis, 2010.

http://lifestyle.fajar.co.id/read/85895/37/ton silitis-akut-dan-kronis.diunduh: November 2012

9. Muhammad, A.F. Tonsilitis Kronis, 2007, http://hennykartika.wordpress.com/?s=tonsi litis+kronis. Diunduh: 5 november 2012

10. Rajesh, Bakashi P, Chatterji M. "Bacterial or Viral" Is Age Indicator in Acute Suppurative Tonsillitis. JK SCIENCE. 2008;10(4):175-177.

11. Manua, JV. KTIS : Pola Kuman Dan Kepekaannya Terhadap Antibiotika Pada Penderita Tonsilitis di Bagian Ilmu Kesehatan THT-KL RSUP. Prof. Dr. R.D. Kandou Periode Juni-Juli 2010. Manado 2012. 